\title{
A preliminary cytogenetic and hematological study of photocopying machine operators
}

\begin{abstract}
The incidences of chromosomal aberrations(CAs) as well as sister chromatid exchange frequencies (SCEs) was evaluated from 12 photocopying machine operators working on an average 8-9 hours per day for more than five years. A complete blood picture of each individual was assessed with an automatic particle cell counter. Additionally, blood pressure was measured at the time of blood collection from all photocopying machine operators. For comparison, the control group included another 12 individuals matched according to age, sex, socioeconomic conditions as well as other personal habits.

The observations of the present study are indicators of health hazard for, although small, there was a significant increase in the percentage of aberrant cells $(P<0.05)$, total aberrations $(P<0.01)$ as well as total aberrations excluding chromatid gaps $(P<0.01)$ among photocopying machine operators when compared to controls. However, results on SCE analysis of photocopying operators revealed no significant difference from the controls. At the same time all photocopying operators exhibited normal hematological parameters as well as blood pressure values.
\end{abstract}

Key Words: Photocopying machine operators, Occupational hazards, Chromosomal aberrations, SCE, Hematology

\section{INTRODUCTION}

Photocopiers are used in many work places, a good source of employment and common machines in Indian markets. The machine works on simple electronics, it just projects light on the document placed on the glass plate, the ink in the roller blade clings to the image area as per the alignment of electrically charged particles on the paper and reproduces or photocopies the original document. The persons who operate the machine are exposed to possible hazards associated with it. 'Toner' is the main component of photocopying machine that mainly consist of carbon black (7\%), polycyclic aromatic hydrocarbons (PAHs), styrene, magnetite, nitropyrenes, benzene, toluene, other volatile substances and low melt polymer resins mixed with minute steel, silica or ferrite beads. Besides these, ozone, nitrogen dioxide, volatile organic compounds like 1-1, biphenyl p-dichlorobenzene pyrolbenzene and tetra chloroethylene aldehydes are also released into the atmosphere by the machine while operating.

Majority of the above mentioned agents have been reported to be mutagenic or genotoxic in either bacterial or mammalian systems. ${ }^{[1-4]}$ So far, there is only one published report where authors Goud et al $l_{1}^{[5]}$ indicated that individuals working with photocopying machines have an increased basal DNA damage, as measured by comet assay.

As far as we are aware, there are no reports on the cytogenetic analysis of individuals working with photocopying machines. Therefore to find out whether exposure to photocopying machines has any genotoxic effect, we performed the present pilot study on 12 photocopying machine (dry toner) operators working on an average 8-9 hours/day for more than five years.

\section{MATERIALS AND METHODS}

Sampling of blood: The study group comprised of 12 photocopying machine operators and 12 controls matched according to age, sex, socioeconomic conditions and other personal habits. All blood samples were collected by skilled hands through venipuncture. About $2 \mathrm{ml}$ of blood was transferred into sodium heparinized vaccutainer tubes for cytogenetic analysis, while remaining $2 \mathrm{ml}$ was transferred into EDTA bulbs for hematological analysis. The samples so obtained were processed within an hour for both hematology as well as cytogenetic analysis.

Prior to the blood collection each in-
P. K. Gadhia, D. Patel, K. B. Solanki, D. N. Tamakuwala, M. A. Pithawala Department of Biosciences, Veer Narmad South Gujarat University, Surat 395007, India

For correspondence: Prof. P. K. Gadhia, Department of Biosciences, Veer Narmad South Gujarat University, UdhanaMagdalla Road, Surat 395007, India. E-mail: pankaj_gadhia@hotmail.com
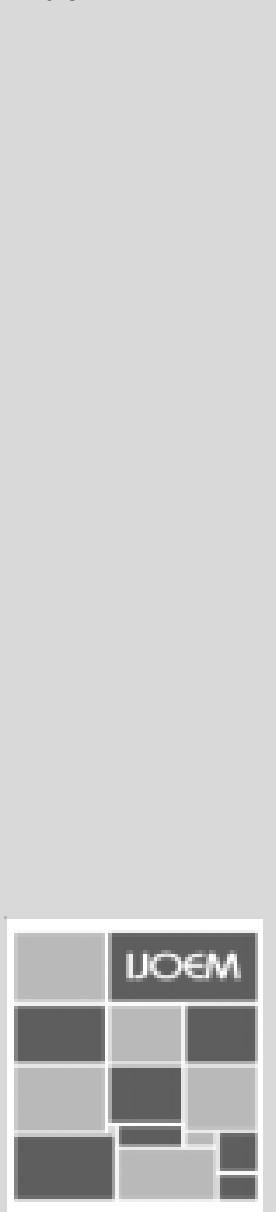
dividual gave an informed consent. A questionnaire about his personal details, working conditions (duration of service, total working hours/day and machine model), habits or addiction, medication, recent history of infection, vaccination, radiological examinations or treatments, if any, was filled in. The particulars of each photocopying machine operator considered in the present study are shown in Table 1. Before blood collection, blood pressure was measured (arms cuff) by mercury type sphygmomanometer.

Lymphocyte cultures and slide preparations: The basic culture method of Hungerford ${ }^{[6]}$ was adopted with some modifications. ${ }^{[7]}$ From each blood sample collected, two separate culture vials were set up, one for CAs and other for SCEs. About $0.6 \mathrm{ml}$ of blood was transferred to each culture vial that contained McCoy's 5-A medium (5 ml), phytohemagglutinin $(0.1 \mathrm{ml})$, foetal calf serum $(1 \mathrm{ml})$, heparin $(0.2 \mathrm{ml})$ and antibiotics streptomycin/penicillin $(0.1 \mathrm{ml})$. These vials were incubated at $37^{\circ} \mathrm{C}$ for 72 hours. Two hours prior to harvesting, $0.1 \mathrm{ml}$ of colchicine was added to block mitosis. Cells were harvested by centrifugation. A brief treatment of hypotonic $(0.075 \mathrm{M} \mathrm{KCl})$ was followed by fixation in 3:1 methanol: acetic acid. The fixation was repeated twice so as to obtain white pellet. The cell suspension was allowed to fall from convenient height onto pre-chilled sterile glass slides and airdried preparations were made. All slides were blind coded and scored randomized to avoid observer's bias.

For SCE analysis, after $24 \mathrm{hrs}$ of incubation $10 \mu \mathrm{g} / \mathrm{ml}$ of 5 bromodeoxyuridine (5 $\mathrm{BrdU}$ ) was added. The slides prepared from these cultures were stained in Hoechst- 33258 for half an hour, mounted in the same and exposed to fluorescence light for 24 hours. Next, the slides were incubated in $2 \times$ SSC (double strength standard sodium citrate) at $60^{\circ} \mathrm{C}$ for an hour. Finally, the slides were washed in distilled water and stained in $7 \%$ Giemsa.

One hundred well spread first division metaphases were scored per individual for CAs while 30 second division metaphases for SCEs. The percentage of cells in first division (M1), second division (M2) and third division (M3) metaphases were counted to calculate replicative index (RI). $\mathrm{RI}=[1 \mathrm{x} \% \mathrm{M} 1+2 \mathrm{x} \% \mathrm{M} 2+3 \mathrm{x} \% \mathrm{M} 3] / 100$.

Hematology: All blood samples were analysed by automatic electronic blood cell counter (Erma PCE-170, Japan) where 18 different parameters were computerized.

Statistics: Student's t-test was employed.

\section{RESULTS}

The results on chromosomal aberrations as well as SCE frequencies of occupationally exposed photocopying machine operators and controls are presented in Table 2. Both, chromatid as well as chromosome type aberrations were recorded from photocopying machine operators. Chromatid type aberrations included chromatid gaps and breaks (Figure 1a) while chromosome type aberrations included chromosome gap, dicentrics (Figure 1b), acentric fragments and endoreduplication.

Mean percentage of aberrant cells were significantly high $(P<0.05)$ among photocopying machine operators $(2.25 \%)$ when compared to controls (0.33\%). Total aberrations counted from controls were $0.33 \%$ while for photocopying machine operators they were $3.33 \%$ (significantly high at $P<0.01$ ). When chromatid gaps (often being visual aberrations) were excluded from total aberrations, the controls exhibited zero percent aberration in comparison to $2 \%$ among photocopying machine operators.

Results on SCE analysis of photocopying machine operators revealed no significant difference from the controls. Simultaneously, replicative index among photocopying machine operators and controls were not significantly different.

Table 1: Particulars of photocopying machine operators

\begin{tabular}{|c|c|c|c|c|c|c|}
\hline Proband & Age/Sex & $\begin{array}{c}\text { Duration of } \\
\text { employment } \\
\text { (years) }\end{array}$ & $\begin{array}{c}\text { Total } \\
\text { working } \\
\text { hours/day }\end{array}$ & $\begin{array}{c}\text { Condition } \\
\text { of } \\
\text { workplace }\end{array}$ & $\begin{array}{l}\text { Addiction } \\
\text { if any }\end{array}$ & $\begin{array}{l}\text { Health status } \\
\text { at the time of } \\
\text { blood collection }\end{array}$ \\
\hline 1 & $40 / \mathrm{M}$ & 06 & 08 & - & Chewing tobacco and betel nut & Good \\
\hline 2 & $43 / \mathrm{M}$ & 23 & 06 & - & - & Coughing, eye burning \\
\hline 3 & $30 / \mathrm{M}$ & 06 & 10 & $A C$ & Alcohol, chewing tobacco & Good \\
\hline 4 & $33 / \mathrm{M}$ & 13 & 08 & $\mathrm{AC}$ & Alcohol, chewing tobacco & Good \\
\hline 5 & $31 / \mathrm{M}$ & 15 & 12 & Congested & Smoking & Good \\
\hline 6 & 23/M & 05 & 10 & Congested & Chewing tobacco and betel nut & Good \\
\hline 7 & $20 / \mathrm{M}$ & 02 & 09 & Congested & - & Good \\
\hline 8 & $39 / \mathrm{M}$ & 04 & 06 & Congested & - & Good \\
\hline 9 & $48 / \mathrm{M}$ & 12 & 09 & Congested & - & Good \\
\hline 10 & $25 / \mathrm{M}$ & 12 & 12 & Congested/AC & - & Good \\
\hline 11 & $25 / \mathrm{M}$ & 10 & 08 & $A C$ & - & Good \\
\hline 12 & 23/M & 10 & 10 & $A C$ & - & Good \\
\hline
\end{tabular}

AC - Air Condition 
Total number of aberrations found from each photocopying machine operator is presented in Figure 2. Since, there were only four individuals among controls who exhibited chromatid gaps and rest showed no aberrations, they have not been presented in the figure.

Hematological study (Table 3) of total RBC, total WBC,

Table 2: Chromosomal aberrations, sister chromatid exchanges and replicative index among photocopying machine operators and controls

\begin{tabular}{llll}
\hline & Controls & $\begin{array}{l}\text { Photocopying } \\
\text { machine operators }\end{array}$ & $P$-value \\
\hline No. of individuals & 12 & 12 & \\
Mean age & $27.66 \pm 3.30$ & $31.66 \pm 2.49$ & \\
Total no. of cells scored & 1200 & 1200 & \\
Total no. of aberrant cells & $4(0.33 \%)$ & $27^{*}(2.25 \%)$ & $<0.05$ \\
Total aberrations & $4(0.33 \%)$ & $40^{*}(3.33 \%)$ & $<0.01$ \\
Total aberrations & & & \\
minus chromatid gaps & 0 & $24^{*}(2.00 \%)$ & $<0.01$ \\
Mean SCE/cell \pm SEM & $3.21 \pm 0.55$ & $3.37 \pm 0.55$ & \\
Mean Replicative index & 1.82 & 1.87 & \\
\hline
\end{tabular}

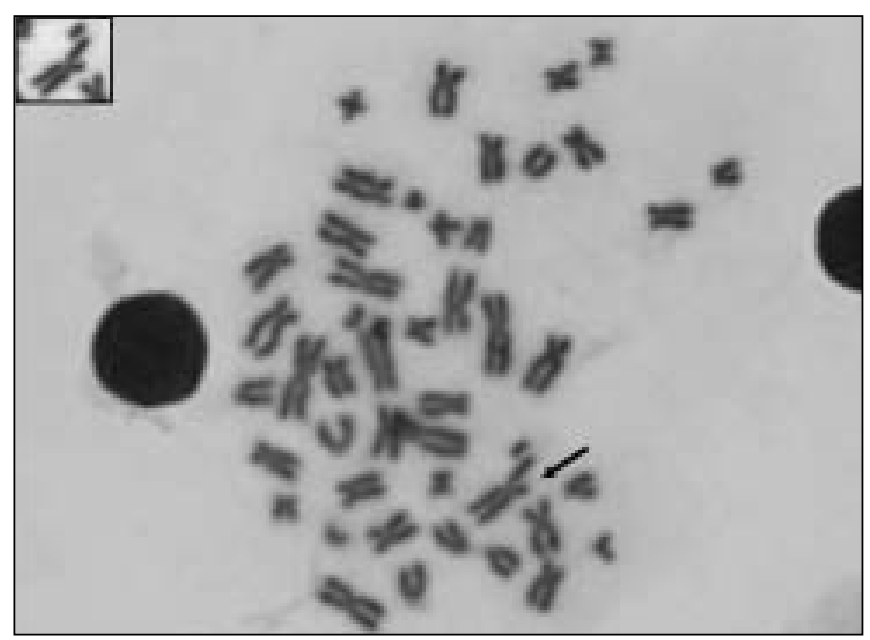

(a) Chromatid break

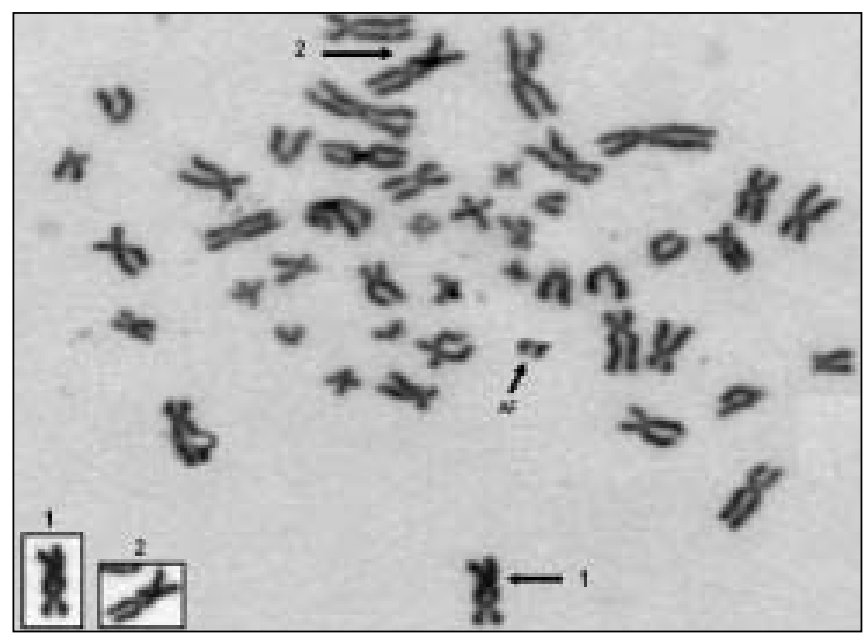

(b) Dicentric chromosomes and acentric fragment (AF)

Figure 1: Chromosomal aberrations observed from photocopying machine operators hemoglobin percentage and platelet count from photocopying machine operators did not reveal untoward variations from the normal values. Measurement of blood pressure at the time of blood collection from photocopying machine operators showed normal patterns for each individual (Figure 3).

\section{DISCUSSION}

The present paper describes results on cytogenetic analysis of peripheral blood lymphocytes from group of individuals working with photocopying machine. On the basis of observed chromosomal aberrations, the workers may be considered a slight risk group, for the environment in which they work is contaminated with volatile organic and inorganic compounds, components of toner, styrene, formaldehyde, ozone and polycyclic aromatic hydrocarbons. Besides, if the machine is damaged or poorly installed in congested atmosphere there are chance for a worker to be exposed to UV radiation.

So far, there are no reports on the cytogenetic analysis of

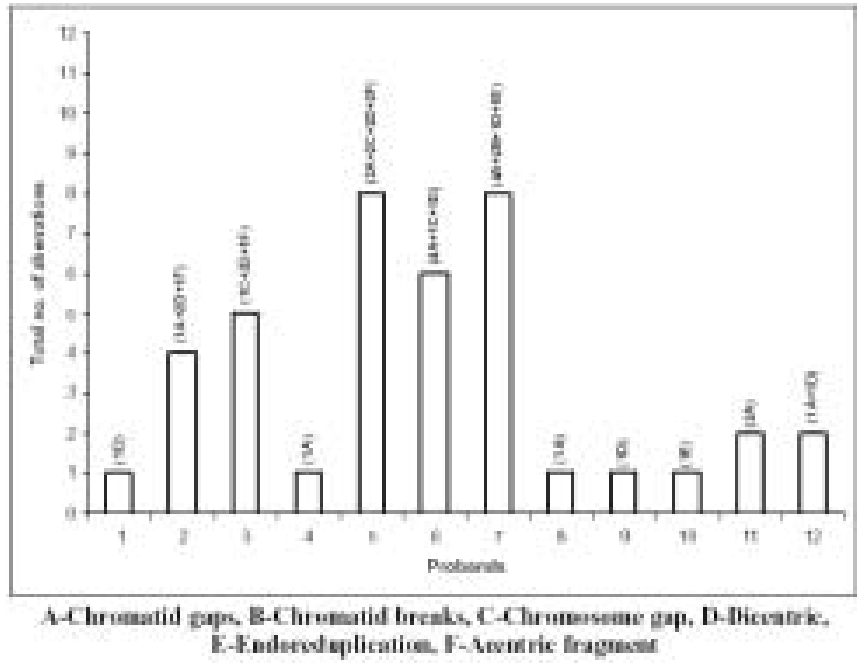

Figure 2: Total number of chromosomal aberrations found from each photocopying machine operators

Table 3: Hematological analysis of photocopying machine operators

\begin{tabular}{|c|c|c|c|c|}
\hline $\begin{array}{l}\text { Normal } \\
\text { Range }\end{array}$ & $\begin{array}{c}\text { Hemoglobin } \\
\text { (gm \%) } \\
12-18\end{array}$ & $\begin{array}{c}\text { RBC (million } \\
\text { /cu.mm) } \\
4.2-6.2\end{array}$ & $\begin{array}{c}\text { WBC (nos. } \\
\text { /cu.mm) } \\
4000 \\
-10,500\end{array}$ & $\begin{array}{c}\text { Platelets } \\
\text { (nos. /cu.mm) } \\
1,50,000 \\
-4,00,000\end{array}$ \\
\hline 1 & 9.0 & 4.63 & 3,900 & $3,39,000$ \\
\hline 2 & 12.7 & 3.96 & 7,400 & $3,17,000$ \\
\hline 3 & 13.0 & 4.30 & 9,700 & $3,00,000$ \\
\hline 4 & 14.2 & 4.62 & 6,500 & $1,90,000$ \\
\hline 5 & 12.4 & 3.78 & 8,100 & $2,86,000$ \\
\hline 6 & 11.9 & 5.52 & 4,800 & $3,19,000$ \\
\hline 7 & 12.6 & 4.48 & 9,600 & $2,71,000$ \\
\hline 8 & 12.9 & 4.70 & 7,200 & $2,15,000$ \\
\hline 9 & 8.4 & 4.00 & 6,000 & $2,25,000$ \\
\hline 10 & 13.2 & 3.84 & 8,400 & $3,50,000$ \\
\hline 11 & 12.2 & 4.19 & 7,800 & $2,84,000$ \\
\hline 12 & 13.1 & 4.74 & 7,400 & $1,88,000$ \\
\hline
\end{tabular}




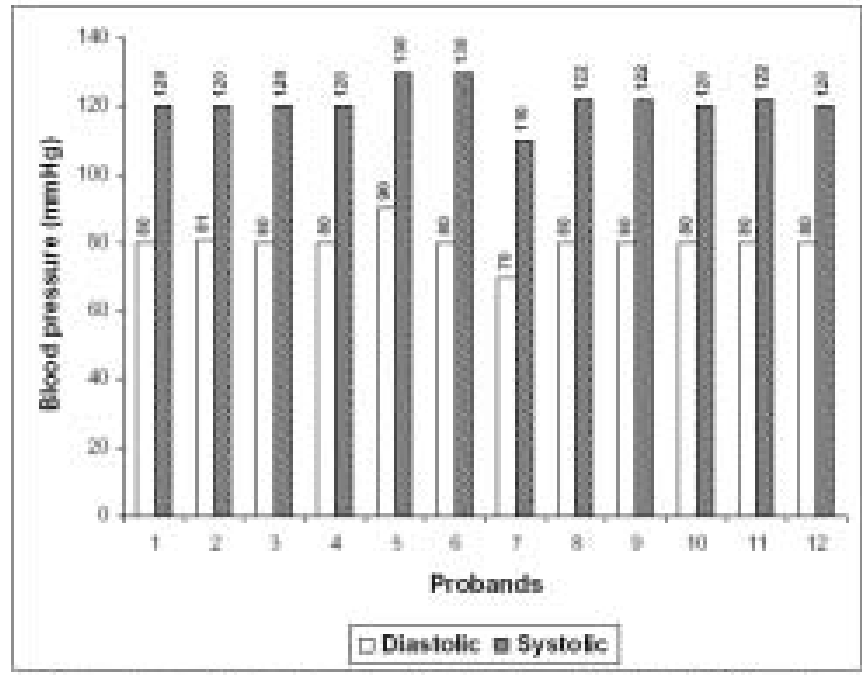

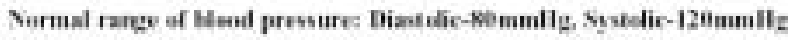

Figure 3: Measurement of blood pressure in photocopying machine operators

photocopying machine operators and therefore, the present study is first of its kind. The results of the present study (particularly CAs) are in good agreement with those of Goud et $\mathrm{al}^{\left[{ }^{[5]}\right.}$ where they demonstrated increased basal DNA damage (by comet assay) among photocopying machine operators in comparison to controls. They also attributed the damage mainly to components present in the toners and their byproducts.

However, in the present study blood pressure measurement, hematological analysis and SCE frequencies did not show much variation from controls. It would be unfair to arrive at any specific conclusion as sample size is smaller in the present study. Nonetheless, a prolonged study with larger sample size and different cytogenetic endpoints would throw a better light onto the question whether or not the particles of toner really cause any genetic damage to the photocopying machine operators.

\section{REFERENCES}

1. Kubika R, Belowskia J, Szczeklika J, Smolikb E, Mielzynskab D, Baja $\mathrm{M}$, et al. Biomarkers of carcinogenesis in humans exposed to polycyclic aromatic hydrocarbons. Mutat Res 1999;445:175-80.

2. Vodikaa P, Tvrdikb T, Osterman-Golkarc S, Vodikovad L, Peterkovaa $\mathrm{K}$, Souekd $\mathrm{P}$, et al. An evaluation of styrene genotoxicity using several biomarkers in a 3-years follow up study of hand lamination workers. Mutat Res 1999;445:205-24.

3. Lofroth G, Hefner E, Alfhelm I, Moller M. Mutagenic activity in photocopies. Science 1980;209:1037-9.

4. Rosenkranz HS, Mccoy EC, Sanders DR, Butles M, Kiriazides DK, Mermelstein R. Nitropyrenes: Isolation, identification, and reduction of mutagenic impurities in carbon black and toners. Science 1980;209:1039-42.

5. Goud KI, Shankarapppa K, Vijayashree B, Rao K, Ahuja YR. DNA damage and repair studies in individuals working with photocopying machine. Int J Hum Genet 2001;1:139-43.

6. Hungerford DA. Leucocytes cultured from small inocula of whole blood and the preparation of metaphase chromosomes by treatment with hypotonic KCl. Stain Tech 1965;40:333.

7. Gadhia P, Shah N, Nahata S, Patel S, Patel K, Pithawala M, et al. Cytogenetic analysis of radiotherapeutic and diagnostic workers occupationally exposed to radiations. Int J Human Genet 2004;4:65-9. 